\title{
Assessment of Bioactivity of Cinnamomum tamala (Buch.-Ham.)
}

\author{
Sukumar Dandapat ${ }^{1 *}$, Manoj Kumar ${ }^{1}$, Manoranjan Prasad Sinha ${ }^{1}$ \\ ${ }^{1 *}$ Department of Zoology, Ranchi University, Ranchi-834008, Jharkhand, India
}

\section{A R T I C LE IN F O}

\section{Article history:}

Received 13 August 2014

Accepted 30 September 2014

Available online, ISSN: $2148-127 \mathrm{X}$

Keywords:

Plants

Antibacterial

Phytochemical

Nutritional

Cytotoxic

${ }^{*}$ Corresponding Author:

E-mail: eaddress.sukumar27@gmail.com

\section{A B S T R A C T}

Bioactivity of medicinal plants is due to presence of various kinds of primary and secondary metabolites. Among studied phytochemicals polyphenol was in higher quantity $(16.7 \pm 0.7 \mathrm{~g} / 100 \mathrm{~g})$. Antipathogenic efficacy of $C$. tamala has been tested against, $S$. typhi (MTCC 3216), P. aeruginosa (MTCC 7837), S. aureus (MTCC 3160), P. mirabilis (MTCC 1249) and B. subtilis (MTCC 736) by agar diffusion method and broth dilution methodand all the strains were affected by methanolic and aqueous leaf extracts of $C$. tamala. The minimum inhibitory concentration (MIC) values in agar diffusion method were $1.25 \mathrm{mg}-5 \mathrm{mg}$ and $2.5 \mathrm{mg}-5 \mathrm{mg}$ for methanolic and aqueous leaf extracts respectively. Complete inhibition was observed in broth dilution method at $1.25 \mathrm{mg} / \mathrm{mL}-9 \mathrm{mg} / \mathrm{mL}$ and $1 \mathrm{mg} / \mathrm{mL}-13 \mathrm{mg} / \mathrm{mL}$ concentration of methanolic and aqueous extracts respectively. The leaf extracts did not show cytotoxic at $0.2 \mathrm{mg} . \mathrm{mL}-1 \mathrm{mg} / \mathrm{mL}$ concentration of aqueous leaf extract but showed haemolysis at $1 \mathrm{mg} / \mathrm{mL}$ concentration of metanolic leaf extract of $C$. tamala. C. tamala leaves showed high nutritional values $(143.5 \pm 0.5 \mathrm{Kcal} / 100 \mathrm{~g})$. The nutritional components like protein, fats, carbohydrates and edible fibres were $6 \pm 0.5,8.5$ $\pm 1.8,9.5 \pm 0.5$ and $30.5 \pm 0.6 \mathrm{~g} / 100 \mathrm{~g}$ respectively. Therefore it can be concluded that leaf extract of $C$. tamala can be used safely against above mentioned human pathogens and for the preparation of new pharmaceutical drug.

\section{Introduction}

Infectious diseases are the foremost cause of premature death and kill about 50000 people every day in the world. In recent years, drug resistance pathogenic bacteria have been commonly reported from all over the world due to indiscriminate use of antibiotics and the situation alarming the development of potent antimicrobial agents (Robin et al., 1998).

S. aureus is a notorious suppurative (pus forming) pathogen, a major cause of hospital acquired (nosocomial) wound infection, urinary tract infection, and food poisoning. B. subtilis causes food poisoning and allergic reaction. $P$. mirabilis is known to cause urethitis, cystitis, pylonephritis, prostatitis and pneumonia. $P$. aeruginosa is an opportunistic pathogen known to cause endocaritis, respiratory tract, central nervous system and opthalmic infections in patients suffering cancer, cystic fibrosis and burns. S. typhi is the causative agents of two diseases typhoid and acute gastroenteritis (Todar, 2012; Dandapat et al., 2013b).

Synthetic antibiotics are the most popular antimicrobial agents during their discovery. However, the emergence of multiple drug resistant pathogenic bacteria has a major cause of failure of the antibacterial drug (Mathias et al., 2000) and synthetic antioxidant are more effective but have side effects. That is why, it is very essential to investigate newer drugs with less resistance as which are cheap and easily available.

Medicinal plants has been used as perennial source of traditional remedies for thousands of years and various modem drugs which are used in treatment of various diseases and disorders have been isolated from natural sources (Dandapat et al., 2013b). In fact, plants produce different bioactive molecules, which act as different types of medicines and play an important role in the maintenance of human health (Farombi, 2003). Nowadays awareness about the use and importance of medicinal Plants have increased, because medicinal plants are easily available, less expensive and have no side effects (Cathrine and Nagaraj, 2011).

Cinnamomum tamala belonging to the family luracceae and has been used for various kind of ailments such as anorexia, dryness of mouth, bladder disorder, diarrhea, typhoid, urethitis etc (Rao, 2008).

The present study was undertaken to investigate the phytochemical screening, nutritional potentiality, cytotoxicity and antibacterial efficacy ofmethanolic and aqueous leaf Cinnamomum tamala extracts against Salmonella typhi, Pseudomonas aeruginosa, Staphylococcus aureus, Proteus mirabilis and Bacillus subtilis. 


\section{Materials and Methods}

\section{Collection of plant material}

The fresh tender leaves were collected from Ranchi district, washed and disinfected by treating with $\mathrm{HgCl}_{2}$ and washed again. The leaves were dried in shade under room temperature for six to seven days, powered and sieved (Kumar et al., 2013a).

\section{Extract preparation}

$50 \mathrm{~g}$ of the fine powder was subjected to extraction by soxhlet using methanol and distilled water separately for methanolic and aqueous extract. The extract obtained was filtered, concentrated and dried in rotary flash evaporator maintained at $45^{\circ} \mathrm{c}$ for proper dehydration methanol free because methanol induce toxicity to living organisms. Percentage yield of each extract was calculated and the dried extract was stored in air tight containers at room temperature for further studies (Kumar et al., 2013h).

\section{Phytochemical screening}

Total phenol was determined by Folin-Ciocalteau reagent following Ramamorthy and Bano (2007). Tannins were quantified as standard published in the quality control methods for medicinal plant materials(WHO, 1998). Aluminium chloride colorimetric method was used with some modifications to determine flavonoids content fowling Lin and Tang (2007). Alkaloid was determined by the method used by Helrich (1990). Saponin content was determined following Obdona and Ochuko (2001). The details have been described elsewhere Kumar et al. (2013b).

\section{Anti-Bacterial analysis}

Antibacterial efficacy of methanolic leaf extract of C. tamala was carried out against Salmonella typhi (MTCC 3216), Pseudomonas aeruginosa (MTCC 7837), Staphylococcus aureus (MTCC 3160), Proteus mirabilis (MTCC 1429) and Bacillus subtilis (MTCC 736) by agar diffusion method comparing with standard antibiotic Gentamycin and by broth dilution method. The details have been described elsewhere Kumar et al. (2013e).

\section{Cytotoxicity}

Cytotoxicity of plant extract was determined by assessing the haemolytic activity of aqueous and methanolic leaf extract using goat blood RBCs. An erythrocyte suspension was prepared by adding $5 \%$ (by volume) of sodium citrate $(36.5 \mathrm{~g} / \mathrm{L})$ to fresh blood and centrifuged at $1000 \mathrm{rpm}$ for $5 \mathrm{~min}$ to separate the erythrocytes. $2 \%$ erythrocyte suspension was prepared by adding $49 \mathrm{~mL}$ phosphate buffer $(\mathrm{pH} \mathrm{7.4)}$ to $1 \mathrm{~mL}$ packed erythrocytes. Serial dilution of plant extracts were prepared using phosphate buffer. $1 \mathrm{ml}$ of citrated blood was mixed with equal volume of diluted plant extracts and the volume was adjusted to $5 \mathrm{~mL}$ by phosphate buffer. The mixture was allowed to stand for 20 minutes at room temperature and $\mathrm{O}$. D. was measured spectrophotometrically at $540 \mathrm{~nm}$ (WHO, 1998; Kumar et al., 2013h).

\section{Nutritional potentiality}

Crude fat, carbohydrate and protein were quantified following previously published standard tests (Watanble and Olsen, 1965; Jayarama, 2005), and nutritive values were calculated on the basis of formula following Nile and Khobragade (2009). The details have been described elsewhere Kumar et al. (2013a).

\section{Results and Discussion}

Phytochemical screening

The results of phytochemical analysis of the leaf samples of Cinnamomum tamala have been presented in fig -1 .The result revealed that polyphenols was highest $(16.7 \pm 0.7 \mathrm{~g} / 100 \mathrm{~g})$ and flavonoids were lowest $(1.0 \pm$ $1.01 \mathrm{~g} / 100 \mathrm{~g}$ ) among all the studied phytochemicals. Similarly Kumar et al. (2013d) reported $6.13 \pm 0.13 \mathrm{~g} / 100 \mathrm{~g}$ tannin, $\quad 2.09 \pm 0.17 \mathrm{~g} / 100 \mathrm{~g}$ saponin, $2.1 \pm 0.21 \mathrm{~g} / 100 \mathrm{~g}$ flavonoids, $0.13 \pm 0.1 \mathrm{~g} / 100 \mathrm{~g}$ poly phenols in A. vasica. Kumar et al. (2013f) also reported $1.38 \pm 0.5 \mathrm{~g} / 100 \mathrm{~g}$ tannin, $4.5 \pm 0.63 \mathrm{~g} / 100 \mathrm{~g}$ saponin, $0.65 \pm 0.2 \mathrm{~g} / 100 \mathrm{~g}$ flavonoid, and $1.73 \pm 0.4 \mathrm{~g} / 100 \mathrm{~g}$ polyphenol and $2.6 \pm 0.5$ g/100 g alkaloid in T. cordifolia. Dandapat et al. (2013b) reported phytochemicals such as tannin, saponins, alkaloids, phenols and flavonoids possess direct or indirect correlation with therapeutic efficacy against various diseases.

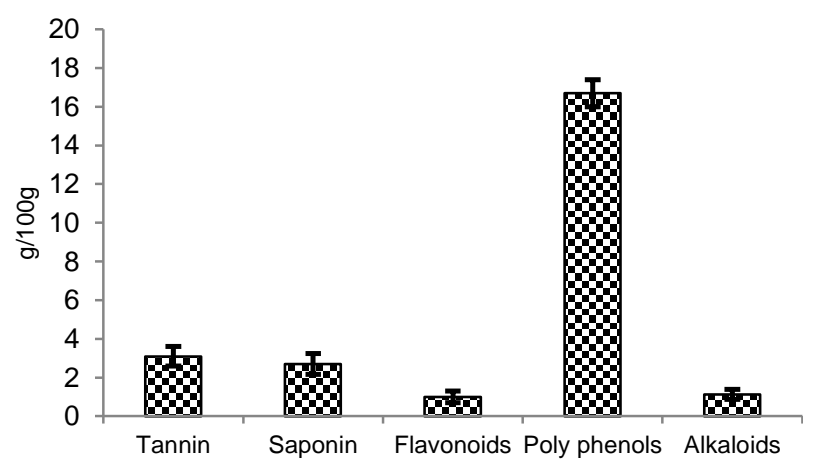

Figure 1 Proximate phytochemical composition of Cinnamomum tamala leaf $(\mathrm{M} \pm \mathrm{SD} ; \mathrm{n}=3)$.

Anibacterial efficacy

The antibacterial efficacy of methanolic extract of $C$. tamala leaf was quantitatively assessed on the basis of inhibition zone (ZOI) in $\mathrm{mm}$ and minimum inhibitory concentration (MIC) following the agar disk diffusion method and percent inhibition by broth dilution method. The test organisms were also inoculated with pure antibiotic-gentamycin to compare the efficacy of leaf extract for their microbial properties (Table -2$)$. In the present investigation the extract was found to be effective all the pathogens. The ZOI (Zone of inhibition) observed for the methanolic (M) and aqueous (A) extract using agar diffusion method is listed in table -1 .

The broth dilution method showed more pronounced antimicrobial activity through $100 \%$ inhibition of all the pathogens in the range of $1.25-10 \mathrm{mg} / \mathrm{mL}$ concentration of methanolic leaf extract (Fig-2). 
Table 1 The zone of inhibition and MIC (in mm) of methanolic leaf extract of C.tamala.

\begin{tabular}{|c|c|c|c|c|c|c|c|c|c|c|}
\hline \multirow{3}{*}{$\begin{array}{l}\text { Concentration } \\
(\mathrm{mg} / \mathrm{mL})\end{array}$} & \multicolumn{10}{|c|}{ Zone of inhibition (ZOI in $\mathrm{mm}$ ) } \\
\hline & \multicolumn{2}{|c|}{ S. typhi } & \multicolumn{2}{|c|}{ P. aeruginosa } & \multicolumn{2}{|c|}{ S. aureus } & \multicolumn{2}{|c|}{ P. mirabilis } & \multicolumn{2}{|c|}{ B. subtilis } \\
\hline & M & $\mathrm{A}$ & $\mathrm{M}$ & A & M & A & M & A & M & A \\
\hline 0.13 & 0 & 0 & 0 & 0 & 0 & 0 & 0 & 0 & 0 & 0 \\
\hline 0.36 & 0 & 0 & 0 & 0 & 0 & 0 & 0 & 0 & 0 & 0 \\
\hline 0.612 & 0 & 0 & 0 & 0 & 0 & 0 & 0 & 0 & 0 & 0 \\
\hline 1.25 & 0 & 0 & 0 & 0 & 0 & 0 & 0 & 0 & 3 & 0 \\
\hline 2.5 & 0 & 0 & 0 & 0 & 6 & & 0 & 0 & 9 & 3 \\
\hline 5 & 3 & 0 & 4 & 2 & 6 & 4 & 10 & 6 & 10 & 6 \\
\hline $\mathrm{MIC}(\mathrm{mg} / \mathrm{mL})$ & 5 & 0 & 5 & 5 & 2.5 & 5 & 5 & 5 & 1.25 & 2.5 \\
\hline
\end{tabular}

Table 2 The zone of inhibition and MIC (in $\mathrm{mm}$ ) of Gentamycin against the test organism.

\begin{tabular}{l|ccccc}
\hline Concentration $(\mu \mathrm{g} / \mathrm{mL})$ & S. typhi & P.aeruginosa & S. aureus & P. mirabilis & S. subtilis \\
\hline 25 & 2 & 0 & 13 & 9 & 8 \\
50 & 13 & 0 & 18 & 13 & 10 \\
100 & 16 & 1 & 21 & 18 & 15 \\
200 & 21 & 3 & 25 & 21 & 19 \\
400 & 25 & 8 & 27 & 25 & 22 \\
800 & 27 & 14 & 34 & 27 & 25 \\
MIC $(\mu \mathrm{g} / \mathrm{mL})$ & 25 & 100 & 25 & 25 & 25 \\
\hline
\end{tabular}

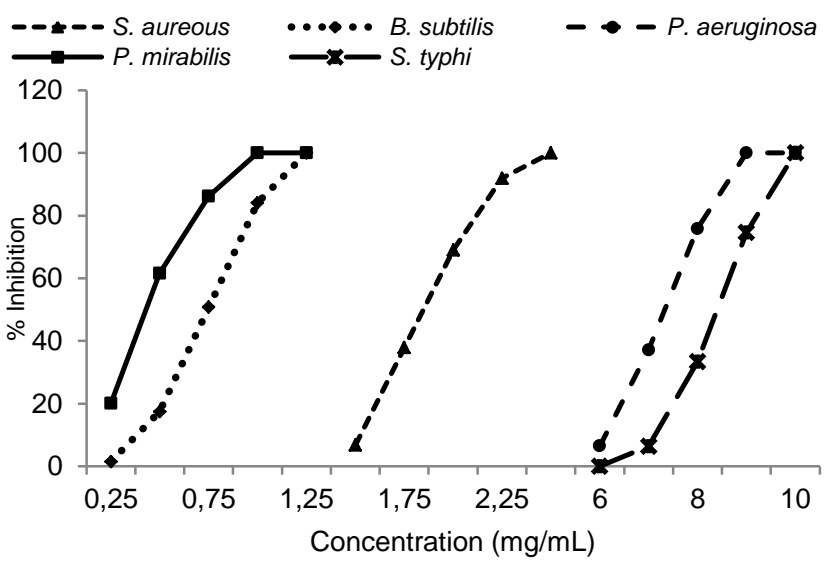

Figure 2 Inhibition (\%) of methanolic leaf extract of $C$. tamala against the pathogens in brothdilution method.

However aqueous leaf extract also showed $100 \%$ inhibition against all the pathogens in higher concentration $(1-13 \mathrm{mg} / \mathrm{mL})$ than methanolic extract presented in figure-3

Jeyasree and Dasarathan (2012) studied the antibacterial effect of $C$. tamala on E. coli, K. pneumonae, $P$. vulgaris, $S$. pneumonae and reported methanolic leaf extract was more effective than aqueous extract because polar and non polar components are effectively extracted in an organic solvent. C.tamala possess anti bacterial activity due to the presence of phenolic compounds such as cinnamic aldehyde, eugenol and cinnamic acid (Baratta et al., 1998). An important characteristic of leaf extract and their components is their hydrophobicity, which enable them to partition the lipids of the bacterial cell membrane and mitochondria, disturbing the cell structure and rendering them more permeable (Sikkema et al., 1994). Extensive leakages from bacterial cells or existance of critical molecules and ions will lead to death (Denyer and Hugo, 1991).

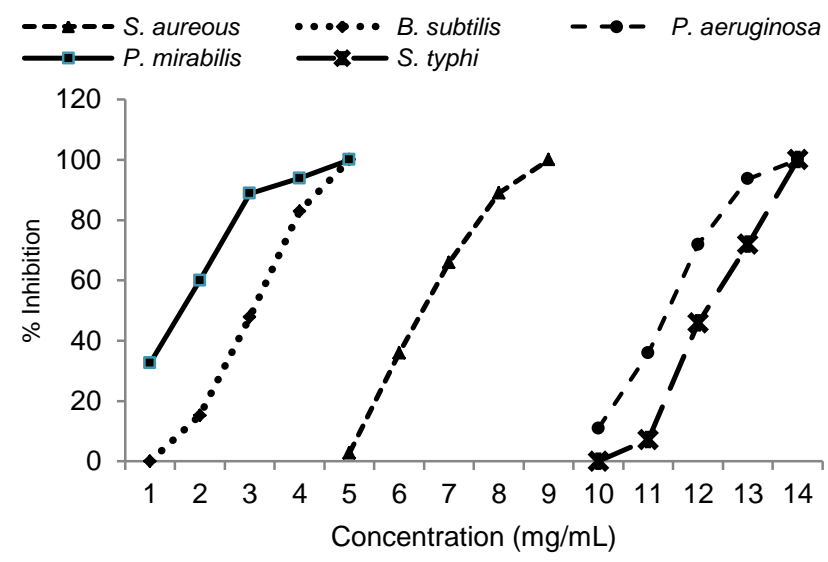

Figure 3 Inhibition (\%) of aqueous leaf extract of $C$. tamala against the pathogensin broth dilution method.

\section{Cytotoxicity}

Result of cytotoxicity performed by haemolytic activity of $C$. tamala and $A$. marmelos leaf extract has been presented in figure- 4 and 5 .

Aqueous leaf extracts of $C$. tamala did not show any changes in OD value at $0.2 \mathrm{mg} / \mathrm{mL}-1 \mathrm{mg} / \mathrm{mL}$ concentration with increase in incubation time period and concentration but the methanolic leaf extract showed deflation at $1 \mathrm{mg} / \mathrm{mL}$ concentration after 15 minutes of incubation. Kumar et al. (2013g) reported $0.2 \mathrm{mg} / \mathrm{mL}$ $0.4 \mathrm{mg} / \mathrm{mL}$ leaf extract of $C$. procerais safe but more concentrated leaf extract increase the hemolytic activity with time of incubation. The plant saponins are known to increase the membrane permeability and hence are considered as potential adjuvants and because due to same property, they cause hemolysis (Urbanska, et al., 2009; Noudeh et al., 2011). This hemolytic activity of a compound depends upon several factors, like the plasma membrane composition, saponin side chain, temperature and time of incubation (Noudeh et al., 2011). The present 
results showed concentration -dependent increase in the hemolytic activity and a slight increase in the same with time of incubation. The hemolytic activity of few plant extracts have been reported (WHO, 1998; Urbanska et al., 2009; Chakraborty and Shah, 2011). By comparing the results, we may say that the haemolytic activity of $C$. tamala is not very pronounced and hence the use of leaf extract is safe.

\section{Nutritional potentiality}

The result of nutritional components of $C$. tamala leaves is very high represented in fig -6 and calculated nutritional values were $143.5 \pm 0.53 \mathrm{Kcal} / 100 \mathrm{~g}$ of leaf sample. Among parameters carbohydrate content was 9.5 $\pm 0.5 \mathrm{~g} / 100 \mathrm{~g}$ and fat content was $6.0 \pm 0.5 \mathrm{~g} / 100 \mathrm{~g}$. The nutritive values of indigenous fruits and vegetables such as Cucumis sativus, Pangiu medule, Brasssica oleraceae, Spinacia oleraceae, Sinapis alba have been reported as 15 Kcal, 227 Kcal, 22Kcal, 29Kcal, 34 Kcal respectively (Hoe and Siong, 1999). Comparing with the above values C. tamala can be used as fodder. Primary metabolites such as carbohydrates, proteins and fats etc, provide nutritional energy during illness (Bukhsh et al., 2007).Dietary fibre is an imperative constituent of a balance healthy diet (Trowel, 1976). Hoe and Sionga (1999) have quantified the crude fiber content of several medicinally important plants like Magnifera grapfithii $(0.9 \%)$, Solanum ferox $(1.9 \%)$, Aleternanthera sessilis $(2.7 \%)$ and Gnetum gnemon (4.7\%). Cinnamomum tamala can be considered a rich source of crude fibre having $30.5 \pm 0.6 \mathrm{~g} / 100 \mathrm{~g}$.

Kumar et al. (2013a) quantify nutritional value of Adhatoda vasicaleaves was $106.00 \mathrm{Cal} / \mathrm{l}$. Nutritionally fibre is beneficial to human boy, since fibre aids absorption of trace elements in the gut and reduces absorption of cholesterol (Kelsay, 1981). Edible fibres are able to bind cancer-causing toxins in the colon, keep them away from the healthy colon cells and provide synergistic protection for colon cells from free radical damage to their DNA (Arvind et al., 2013). Carbohydrate constitutes a broad class of naturally occurring organic compounds that are essential for the maintenance of life (Ebun-Oluwa and Alade, 2007). Proteins contain amino acids utilized by the body cells to synthesize numerous proteins required for the body and also provide energy (Robinson, 2007). Due to moderate level of crude fat in the leaves, people suffering from overweight or obesity can consume in diet (Dandapat et al., 2013a).

\section{Conclusion}

The present study suggest Cinnamomum tamala leaf can be used as potent antibacterial medicine, which inhibits the growth of pathogenic bacteria, sources of many diseases, and the leaves can be used as fodder due to high nutritional value.

\section{Acknowledgement}

The authors acknowledged the facilities provided by the Department of Zoology, Ranchi University, Ranchi.

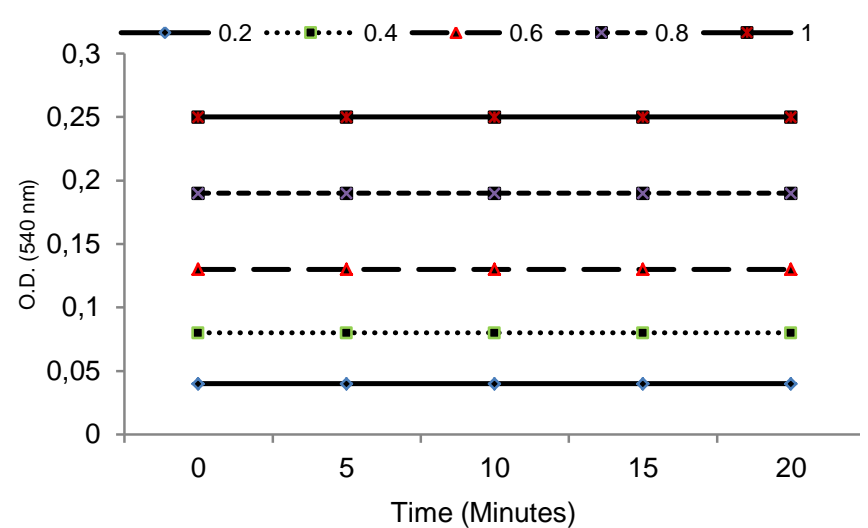

Figure 4 Haemolytic activity of aqueous leaf extract of $C$. tamala.

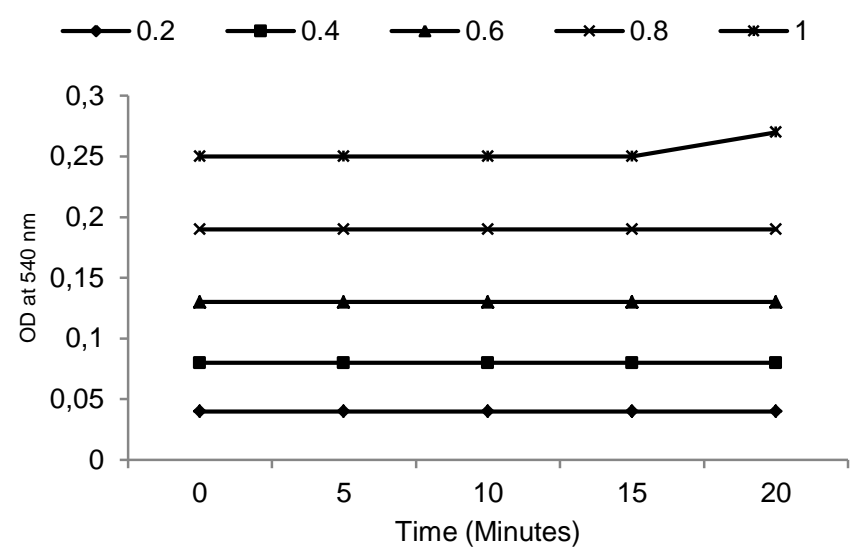

Figure 5 Haemolytic activity of methanolic leaf extract of C. tamala

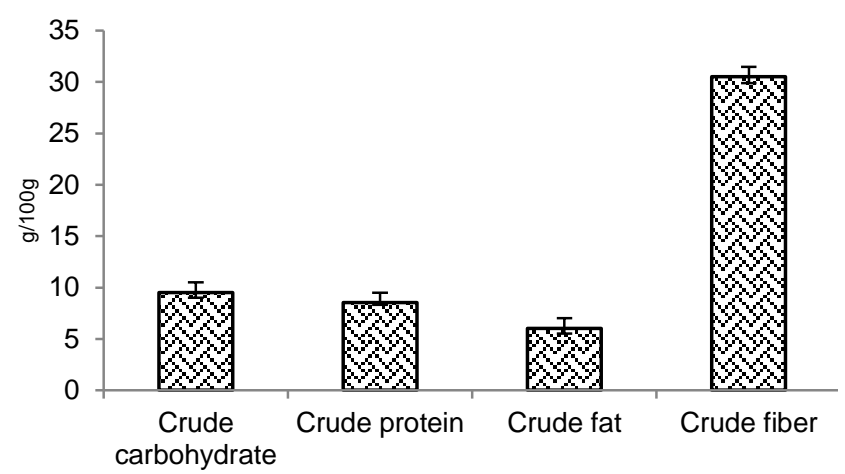

Figure 6 Nutritional composition of $C$. tamala leaf in $\mathrm{g} / 100 \mathrm{~g}(\mathrm{M} \pm \mathrm{SD} ; \mathrm{n}=3)$.

\section{References}

Aravind G, Bhowmik D, Duraivel S, Harish G. 2013. Traditional and medicinal uses of Carica papaya. J Med. Plant Studies. 1(1): 7-15.

Baratta MT, Dorman HJ, Deans SG, Figueiredo AC, Barroso JG, Ruberto G. 1998. Antimicrobial and antioxidant properties of some commercial essential oils. Flav. Fragr. J. 13: 235-244.

Cathrine L, Nagaraj P. 2011. Preliminary phytochemical analysis and antibacterial activity of leaf extracts of Vitexleucoxlon L.F. Int. J Curr. Pharma. Res. 13: 71-73. 
Chakraborty, D. and Shah B. 2011. Antimicrobial, AntiOxidant and Anti-hemolytic activity of Piper betel leaf extracts. International Journal of Pharmacy and Pharmaceutical Sciences, 3: 192-199.

Dandapat S, Kumar M, Kumar A, Sinha MP. (2013)a. Antipathogenicefficacy of methanolic leaf extract of Cinnamomum tamala and Aegle marmelos (L.) with their nutritional potentiality. The Bioscan. 8(2): Supplement on Medicinal Plants. 635-641.

Dandapat Dandapat S, Kumar M, Kumar A, Sinha MP. (2013)b. Therapeutic efficacy and nutritional potentiality of Cinamomum tamala. Int. J. Pharm. 3: 779-785.

Denyer SP, Hugo WB. 1991. Biocide-included damage to the bacterial cell membrane. The society for applied bacteriology, Technical series No.-27. Oxford Blackwell scientific publication, Oxford: pp. 171-188.

Ebun-Oluwa PO, Alade AS. 2007. Nutritional potential of Berlandier Nettle spurge (Jatrophacathatica) seed. Pak. J. Nutrition. 6: 345-348.

Farombi EO. 2003. African indigenous plants with chemotherapeutic potentials and biotechnological approach to the production of bioactive prophylactic agents. Afr. J Biotechnol.2: 662-671.

Hoe VB, Siong KH. 1999. The nutritional value of indigenous fruits and vegetables in Sarawak. Asi. Peci. J Clin. Nutr. 8: 24-31.

Jeyasree P, Dasarathan P. 2012. Screening of phytochemicals and immuneomodulatory potential of amedicinal plant, Cinnamomum tamala. Int. J Pharma. Sci. Res. 3:10491052.

Kelsay JL. 1981. Effects of diet fibre on bowel function and trace mineral balances of human subjects (pp: 2-5). Cereal Chem.

Kumar A, Dandapat S, Kumar M, Sinha MP. (2013)f. Phytochemical properties and antioxidant activity of Calotropis procera (Ait.) R. Br. The Ecoscan; Special issue. 4: $195-200$

Kumar A, Dandapat S, Kumar M, Sinha MP. (2013)g. Evaluation of genotoxicity and cytotoxicity of Tinospora cordifolia (Thunb.). The Bioscan 8(3): Supplement on Toxicology. 1083-1087.

Kumar A, Dandapat S, Kumar M, Sinha MP. (2013)h. Antipathogenic efficacy and aemolytic activity of Calotropis procera leaves. World Journal of Zoology. 8(4): 366-370.

Kumar A, Kumar M, Dandapat S, Sinha MP. 2013c. Antioxidant activity and Pharmacological screening of Tinospora cordifolia. The Bioscan. 8(2): Supplement on Medicinal Plants. 689-693.
Kumar M, Dandapat S, Kumar A, Sinha MP. (2013)a. Determination of nutritive value and mineral Elements of Five- Leaf Chaste Tree (Vitex negundo) And Malabar Nut (Adhatoda vasica Nees). Acad. J. Plant Sci. 6(3): 103-108.

Kumar M, Dandapat S, Kumar A, Sinha MP. (2013)b. Antityphoid activity of Adhatoda vasica and Vitex negundo. Persian Gulf crop protection. 2: 64-75.

Kumar M, Dandapat S, Kumar A, Sinha MP. (2013)e. Growth inhibitory impact of A. vasica and $V$. negundo on some human pathogen. The Ecoscan; Special issue. 4: 241-245.

Kumar M, Kumar A, Dandapat S, Sinha MP. (2013)d. Phytochemical Screening and Antioxidant potency of Adhatoda vasica and Vitexnegundo. The Bioscan 8: Supplement on medicinal plants: 727-730.

Mathias AJ, Somashekar RK, Sumithraand S, Subramanya S. 2000. An Assessment of Reservoirs of Multi-resistanct Nosocomial Pathogens in a Secondary care hospital. Indian J. Microbiol. 40: 183-190

Nile SH, Khobragade CNN. 2009. Determination of nutritive value and mineral elements of some important medicinal plants from western part of India. J Med. Plant. 8(5): 79-88.

Noudeh GD, Sharififar F, Behravan E, Mohajeri E, Alinia V. 2011. Medicinal plants as surface activity modifiers. Journal of Medicinal Plants Research. 5: 5378-5383.

Robin EH, Anril W, Alexander M, Loeto M, Keith K. 1998. Nasopharyngeal carriage and antimicrobial resistance in isolates of Streptococcus pneumonia and Haemophilus influenza Type-b in children under 5 years of age in Botswana. Int. J Infect. Dis. 3: 18-25.

Robinson, H. (1978). Fundalmentals of normal nutrition. 3rd Edition. Macmillan Publishing Co. pp. 41-284.

Sikkema J, Bont de JAM, Poolman B. 1994. Interactions of cyclic hydrocarbons with biological membranes. J Biol. Chem. 26: 1022-8028.

Todar K. 2012. Online textbook of Bacteriology. http://www.textbookofbacteriology.net

Trowel H. 1976. Definition of dietary fiber and hypotheses that it is a positive factor in certain diseases. American J Clin. Nutrit. 29: 417- 421.

Urbanska N, Nartowska J, Skorupska A, Ruszkowski D, Giebultowicz J, Olszowska O. 2009. Determination of hemolytic activity of saponins in hairy root culture of Platycodon grandifolium. ADC. Herba Polonica. 55: 103108.

WHO. 1998. Quality control methods for medicinal plant materials. Library Cataloguing in Publication data, pp. 44. 